\title{
Quantitative evaluation of low back and labor pain. Memory of pain experienced during labor and the intensity of low back pain in older women with discopathy
}

\section{BACKGROUND}

The aim of this study was to determine the intensity of previously experienced labor pains in the context of self-evaluated intensity of discopathy-related low back pain in female patients.

\section{PARTICIPANTS AND PROCEDURE}

The retrospective study included 57 women who received neurosurgical consultation under ambulatory conditions. The intensity of low back pain experienced by every patient was scored using the 11-grade Numeric Rating Scale (NRS-11; ranging from 0 to 10 points). Simultaneously, an obstetrical history was collected from every patient (year of delivery, intensity of labor pain assessed with NRS-11).

\section{RESULTS}

Overall, 57 women, aged between 27 and 88 years (mean $52.8 \pm 15.6$ years), were examined. The age at delivery ranged between 17 and 35 years (mean $25.6 \pm 5.6$ years). The patient-reported intensity of pain in the lumbosacral spine, assessed with NRS-11, ranged between 5 and 10 points (mean $7.9 \pm 1.7$ points), while the intensity of labor pain ranged between 3 and 10 points (mean $8.6 \pm 1.9$ points). Labor pain was perceived as more significantly intense than low back pain localized in the lumbosacral spine. In four cases (7\%), the intensity of low back pain was re-scored upon asking about the intensity of previous labor pain.

\section{CONCLUSIONS}

Labor pain experienced during full-term vaginal delivery is characterized by significantly higher intensity as compared to low back pain. The memory of pain experienced during previous labors can attenuate the intensity of discopathy-related low back pain.

\section{KEY WORDS}

discopathy; labor pain; low back pain; pain memory; pain score

organizations - 1: Department of Neurosurgery, Public Provincial Hospital, Szczecin, Poland · 2: NZOZ Meditest,

Department of Medical Diagnostics, Szczecin, Poland

authors' Contribution - A: Study Design - B: Data Collection - C: Statistical Analysis - D: Data Interpretation .

E: Manuscript Preparation - F: Literature Search - G: Funds Collection

Corresponding Author - Leszek Herbowski, M.D., Department of Neurosurgery, Public Provincial Hospital,

4 Arkońska Str., 71-455 Szczecin, Poland, e-mail: leszekherbowski@data.pl 


\section{BACKGROUND}

Pain is a subjective phenomenon, evaluation of which is modulated by previous pain experiences of the patient. These experiences represent a complex entity which, aside from somatic and emotional factors, includes cognitive, interpersonal, social, and cultural components (de Walden-Gałuszko, Majkowicz, Janiszewska \& Jankowska, 2008); all can affect coping with experienced pain. Potential consequences of
Leszek Herbowski, Podolska Magdalena experienced pain include diminished physical, social, and professional capacities that frequently have a negative impact on the mental status of the affected individuals, causing anxiety, depression, anger, or the feeling of losing control over a variety of life situations (de Walden-Gałuszko, 2001; Golec, 2000, 2004; Golec \& Dobrogowski, 2004; Fernandez, 2002; Parada-Turska, Piotrowski \& Szczepański, 2002).

It can be stated that pain is a ubiquitous complaint, associated with various pathological conditions and physiological states, e.g. delivery. Thus, pain is a psychosomatic phenomenon which, according to the International Association for the Study of Pain (IASP), is defined as an unpleasant sensory and emotional experience associated with actual or potential tissue damage, or described in terms of such damage (IASP, 2012). As mentioned previously, pain is a subjective, complex experience that is perceived on an individual basis and, consequently, constitutes the basis for its great diversity (de Walden-Gałuszko, 2007; de Walden-Gałuszko et al., 2008; Hadjistavropoulos \& Craig, 1994).

Response to pain is to a large degree defined by the cognitive-evaluative assessment associated with the functions of memory, experience of pain, motivation, and hierarchy of values represented by the patient (Barkwell, 1991; Bushnell Villemure \& Duncan, 2004).

The way one perceives pain is to a large extent defined by the type and intensity of one's emotional reactions: anxiety, despondence, and anger (Gallagher \& Verma, 2004; Kerns, Rosenberg \& Jacob, 1994). However, the predominant predictive factors of experiencing labor pain include anxiety associated with approaching delivery, fear of losing control over its course, concerns with regards to the health status of the child, feeling of the lack of thoughtful and reliable care offered by the medical personnel present in the labor room, traumatic experiences associated with previous deliveries, and the lack of reliable knowledge on the course of delivery (Banasiewicz \& Wójtowicz, 2010; Podolska, 2001; Podolska \& Majewska, 2007). Other vital factors defining the experience of labor pain include: personality traits, approach to coping with difficult situations, the sense of self-efficiency, and the occurrence of psychological problems prior to and during the pregnancy, including symptoms of depression, as well as obsessive-compulsive disorders that can influence the level of pain tolerance (Bielawska-Batorowicz, 2006).

Emotional status of an individual who experiences pain modulates the threshold for its tolerance, defined as the maximum level of pain that a person is able to tolerate (de Walden-Gałuszko, 2007). Thus, the determination of the degree of pain intensity is an important prerequisite, both for the patient and the physician, in the decision making process in regards to the implementation of analgesic or surgical treatment. Consequently, an important aspect of the subjective examination is an appropriate, meaning reliable and credible, assessment of pain intensity (Hawker, Mian, Kendzierska \& French, 2011).

The aim of this study was to determine the intensity of previously experienced labor pains in the context of self-evaluated intensity of discopathy-related low back pain in female patients.

\section{PARTICIPANTS AND PROCEDURE}

The retrospective study included 57 women who received neurosurgical consultation under ambulatory conditions. The protocol of this study was approved by the Local Bioethical Committee of the Regional Medical College in Szczecin (decision no. 05/KB/III/ 2009). The patients were consulted in 2011, between January and December, due to the discopathy-related pain in the lumbosacral spine.

The intensity of low back pain experienced by every patient was scored using the 11-point Numeric Rating Scale (NRS-11; ranging from 0 to 10 points). Simultaneously, an obstetrical history was collected from every patient (year of delivery, intensity of labor pain assessed with NRS-11). Basic patients' characteristics are summarized in Table 1.

Obtained data were analyzed statistically with the aid of Microsoft Excel 2010 spreadsheet. The intensity of labor pain was compared to that of low back pain localized in the lumbosacral spine with Student's $t$-test. Power and direction of relationships between the analyzed pain scores and demographic and clinical characteristics of participants were determined using Pearson's coefficient of linear correlation $(r)$. The level of significance of all statistical tests was set at $p<0.05$.

\section{RESULTS}

Overall, 57 women, aged between 27 and 88 years (mean of $52.8 \pm 15.6$ years), were examined. The obstetrical anamnesis revealed that all the participants had a history of at least one vaginal delivery between 1948 and 2009, including one $(n=17)$, two $(n=29)$, three $(n=9)$, four $(n=1)$, or six labors $(n=1)$. Generally, the examined women delivered 59 male and 
Table 1

Characteristics of studied women

\begin{tabular}{|c|c|c|c|c|}
\hline No. & Age at consultation & $\begin{array}{c}\text { Number of } \\
\text { deliveries }\end{array}$ & Year of delivery & Age at delivery \\
\hline \multirow[t]{2}{*}{1} & 63 & 2 & 1969 & 21 \\
\hline & & & 1973 & 25 \\
\hline \multirow[t]{6}{*}{2} & 49 & 6 & 1999 & 37 \\
\hline & & & 1997 & 35 \\
\hline & & & 1984 & 22 \\
\hline & & & 1986 & 24 \\
\hline & & & 1988 & 26 \\
\hline & & & 1989 & 27 \\
\hline \multirow[t]{2}{*}{3} & 39 & 2 & 1997 & 25 \\
\hline & & & 2008 & 36 \\
\hline 4 & 78 & 1 & 1975 & 44 \\
\hline \multirow[t]{2}{*}{5} & 49 & 2 & 1991 & 29 \\
\hline & & & 1994 & 32 \\
\hline \multirow[t]{2}{*}{6} & 58 & 2 & 1971 & 18 \\
\hline & & & 1983 & 30 \\
\hline \multirow[t]{3}{*}{7} & 41 & 3 & 2001 & 31 \\
\hline & & & 1997 & 27 \\
\hline & & & 1999 & 29 \\
\hline 8 & 77 & 1 & 1963 & 19 \\
\hline 9 & 53 & 1 & 1989 & 31 \\
\hline 10 & 29 & 1 & 2006 & 24 \\
\hline \multirow[t]{3}{*}{11} & 59 & 3 & 1974 & 22 \\
\hline & & & 1976 & 24 \\
\hline & & & 1983 & 31 \\
\hline \multirow[t]{2}{*}{12} & 41 & 2 & 1988 & 18 \\
\hline & & & 1997 & 27 \\
\hline \multirow[t]{2}{*}{13} & 35 & 2 & 1996 & 20 \\
\hline & & & 2003 & 27 \\
\hline \multirow[t]{2}{*}{14} & 59 & 2 & 1973 & 21 \\
\hline & & & 1980 & 28 \\
\hline \multirow[t]{3}{*}{15} & 56 & 3 & 1976 & 21 \\
\hline & & & 1978 & 23 \\
\hline & & & 1983 & 28 \\
\hline \multirow[t]{3}{*}{16} & 33 & 3 & 1998 & 20 \\
\hline & & & 2004 & 26 \\
\hline & & & 2007 & 29 \\
\hline
\end{tabular}

(Table 1 continues) 
Table 1

(Table 1 continued)

\begin{tabular}{|c|c|c|c|c|}
\hline No. & Age at consultation & $\begin{array}{c}\text { Number of } \\
\text { deliveries }\end{array}$ & Year of delivery & Age at delivery \\
\hline \multirow[t]{2}{*}{17} & 27 & 2 & 2001 & 17 \\
\hline & & & 2009 & 25 \\
\hline \multirow[t]{2}{*}{18} & 37 & 2 & 1999 & 25 \\
\hline & & & 2008 & 34 \\
\hline \multirow[t]{3}{*}{19} & 50 & 3 & 1981 & 20 \\
\hline & & & 1983 & 22 \\
\hline & & & 1984 & 23 \\
\hline \multirow[t]{3}{*}{20} & 35 & 3 & 1994 & 18 \\
\hline & & & 1997 & 21 \\
\hline & & & 2005 & 29 \\
\hline 21 & 59 & 1 & 1970 & 18 \\
\hline \multirow[t]{2}{*}{22} & 79 & 2 & 1954 & 22 \\
\hline & & & 1963 & 31 \\
\hline \multirow[t]{3}{*}{23} & 50 & 3 & 1985 & 24 \\
\hline & & & 1987 & 26 \\
\hline & & & 1995 & 34 \\
\hline \multirow[t]{2}{*}{24} & 71 & 2 & 1972 & 32 \\
\hline & & & 1978 & 38 \\
\hline \multirow[t]{2}{*}{25} & 57 & 2 & 1978 & 24 \\
\hline & & & 1983 & 29 \\
\hline \multirow[t]{2}{*}{26} & 45 & 2 & 1986 & 20 \\
\hline & & & 1989 & 23 \\
\hline \multirow[t]{2}{*}{27} & 34 & 2 & 2001 & 24 \\
\hline & & & 2008 & 31 \\
\hline \multirow[t]{2}{*}{28} & 60 & 2 & 1972 & 21 \\
\hline & & & 1988 & 37 \\
\hline \multirow[t]{2}{*}{29} & 38 & 2 & 1991 & 18 \\
\hline & & & 1999 & 26 \\
\hline \multirow[t]{2}{*}{30} & 61 & 2 & 1977 & 27 \\
\hline & & & 1981 & 31 \\
\hline \multirow[t]{2}{*}{31} & 78 & 2 & 1963 & 20 \\
\hline & & & 1970 & 27 \\
\hline \multirow[t]{2}{*}{32} & 88 & 2 & 1948 & 25 \\
\hline & & & 1953 & 30 \\
\hline \multirow[t]{3}{*}{33} & 78 & 3 & 1953 & 20 \\
\hline & & & 1955 & 22 \\
\hline & & & 1966 & 33 \\
\hline 34 & 35 & 1 & 2001 & 25 \\
\hline
\end{tabular}

(Table 1 continues) 
Table 1

(Table 1 continued)

\begin{tabular}{|c|c|c|c|c|}
\hline No. & Age at consultation & $\begin{array}{c}\text { Number of } \\
\text { deliveries }\end{array}$ & Year of delivery & Age at delivery \\
\hline 35 & 45 & 1 & 1993 & 27 \\
\hline \multirow[t]{2}{*}{36} & 56 & 2 & 1974 & 19 \\
\hline & & & 1984 & 29 \\
\hline 37 & 31 & 1 & 2005 & 25 \\
\hline 38 & 54 & 1 & 1979 & 22 \\
\hline 39 & 28 & 1 & 2006 & 23 \\
\hline 40 & 56 & 1 & 1976 & 21 \\
\hline 41 & 75 & 1 & 1955 & 19 \\
\hline 42 & 44 & 1 & 1988 & 21 \\
\hline \multirow[t]{2}{*}{43} & 55 & 2 & 1980 & 24 \\
\hline & & & 1981 & 25 \\
\hline \multirow[t]{4}{*}{44} & 43 & 4 & 1988 & 20 \\
\hline & & & 1995 & 27 \\
\hline & & & 1996 & 28 \\
\hline & & & 2008 & 40 \\
\hline 45 & 40 & 1 & 1997 & 26 \\
\hline \multirow[t]{2}{*}{46} & 48 & 2 & 1991 & 28 \\
\hline & & & 1996 & 33 \\
\hline 47 & 36 & 1 & 1998 & 23 \\
\hline \multirow[t]{2}{*}{48} & 54 & 2 & 1978 & 21 \\
\hline & & & 1981 & 24 \\
\hline \multirow[t]{2}{*}{49} & 59 & 2 & 1974 & 22 \\
\hline & & & 1979 & 27 \\
\hline \multirow[t]{2}{*}{50} & 28 & 2 & 2002 & 19 \\
\hline & & & 2006 & 23 \\
\hline \multirow[t]{2}{*}{51} & 78 & 2 & 1954 & 21 \\
\hline & & & 1960 & 27 \\
\hline 52 & 69 & 1 & 1972 & 30 \\
\hline \multirow[t]{2}{*}{53} & 67 & 2 & 1967 & 23 \\
\hline & & & 1969 & 25 \\
\hline \multirow[t]{3}{*}{54} & 59 & 3 & 1970 & 18 \\
\hline & & & 1973 & 21 \\
\hline & & & 1997 & 45 \\
\hline \multirow[t]{2}{*}{55} & 49 & 2 & 1983 & 21 \\
\hline & & & 1991 & 29 \\
\hline \multirow[t]{2}{*}{56} & 73 & 2 & 1957 & 19 \\
\hline & & & 1959 & 21 \\
\hline 57 & 61 & 1 & 1970 & 20 \\
\hline
\end{tabular}

Quantitative evaluation of low back and labor pain 
53 female full-term newborns. The age at delivery ranged between 17 and 35 years (mean of $25.6 \pm 5.6$ years of age). The patient-reported intensity of pain in the lumbosacral spine, assessed with NRS-11, ranged between 5 and 10 points (mean of $7.9 \pm 1.7$ points), while the intensity of labor pain ranged between 3 and 10 points (mean of $8.6 \pm 1.9$ points). The intensity of labor pain and low back pain is presented graphically in Figure 1 and the detailed characteristics of pain according to NRS-11 are summarized in Figures 2 and 3.

The value of Fisher's test for analyzed types of pain was 0.3248 , suggesting their similar variability (equal variances). Additionally, Student's $t$-test revealed significant difference between the patient-assessed in- tensity of labor and low back pain $(p=0.0037)$; labor pain was perceived as more significantly intense than low back pain localized in the lumbosacral spine. The numbers of women experiencing maximal intensity of labor pain and low back pain are compared in Figure 4; the difference between these two groups proved statistically significant $(p=0.0037)$.

Two groups were distinguished among women participating in the study. Group A included women who delivered more than 20 years before the neurosurgical consultation. This group included 71 deliveries taking place $36.3 \pm 11.5$ years prior to the consultation. Group B comprised women who delivered within the last 20 years prior to the neurosurgical consultation. This group included a total of 41 deliveries,

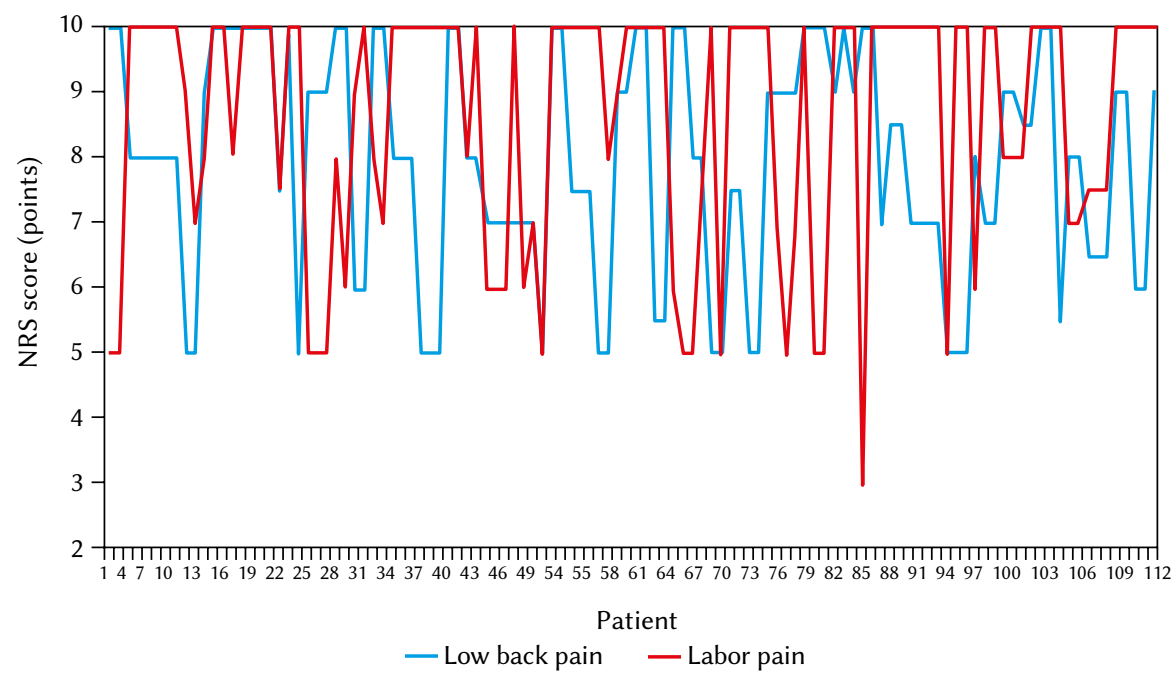

Figure 1. Intensity of low back pain and labor pain according to NRS-11 scale in all the women participating in this study.

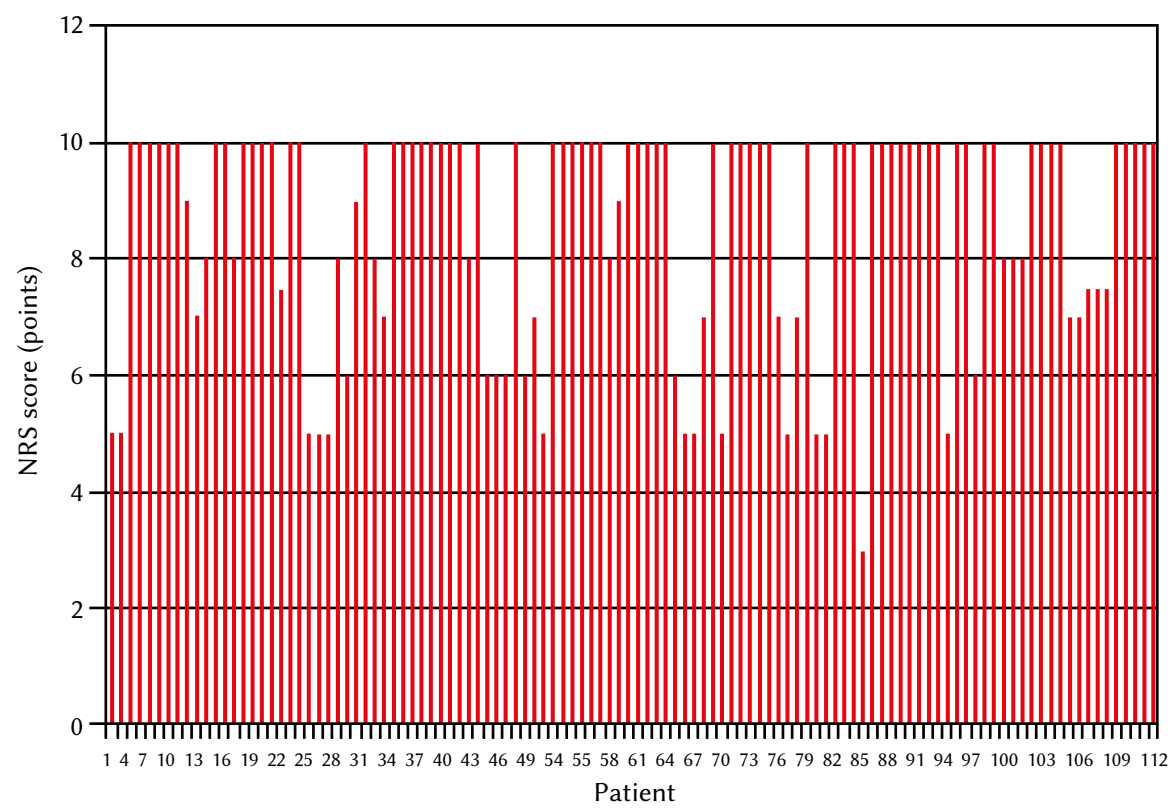

Figure 2. Intensity of labor pain according to NRS-11 scale in all the women participating in this study. 


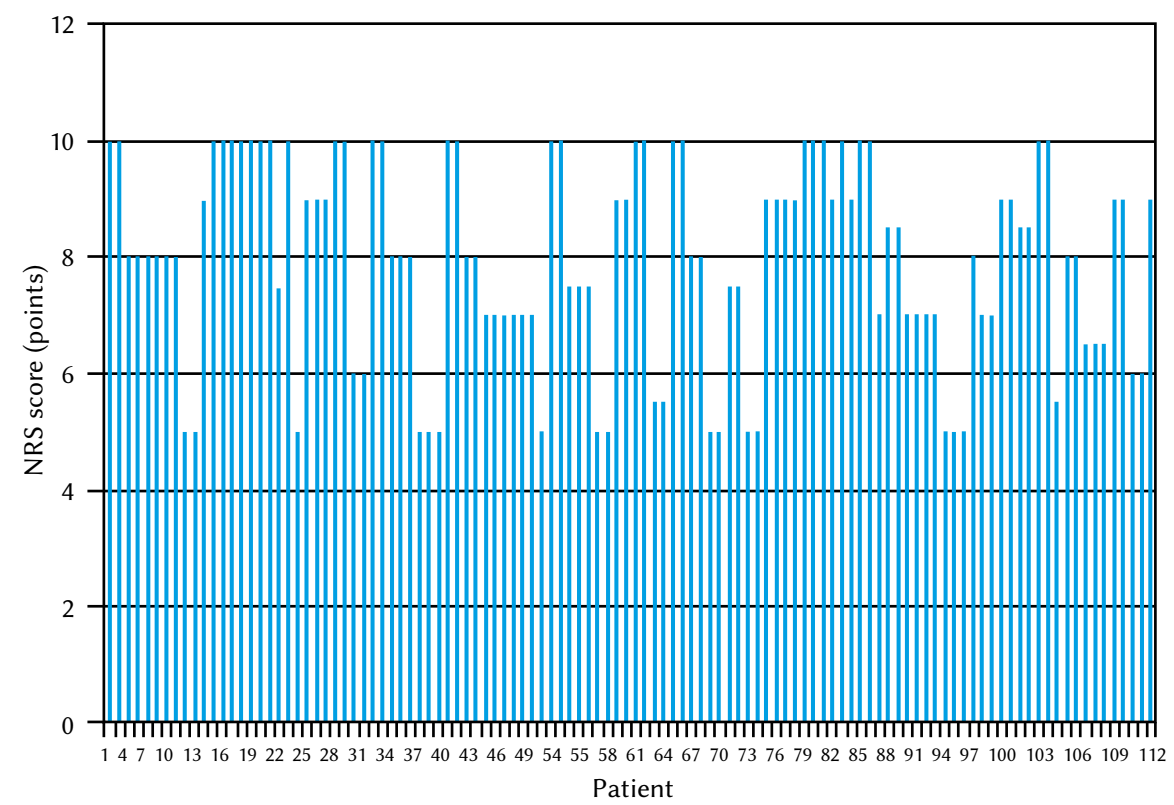

Quantitative evaluation of low back and labor pain

Figure 3. Intensity of low back pain according to NRS-11 scale in all the women participating in this study.

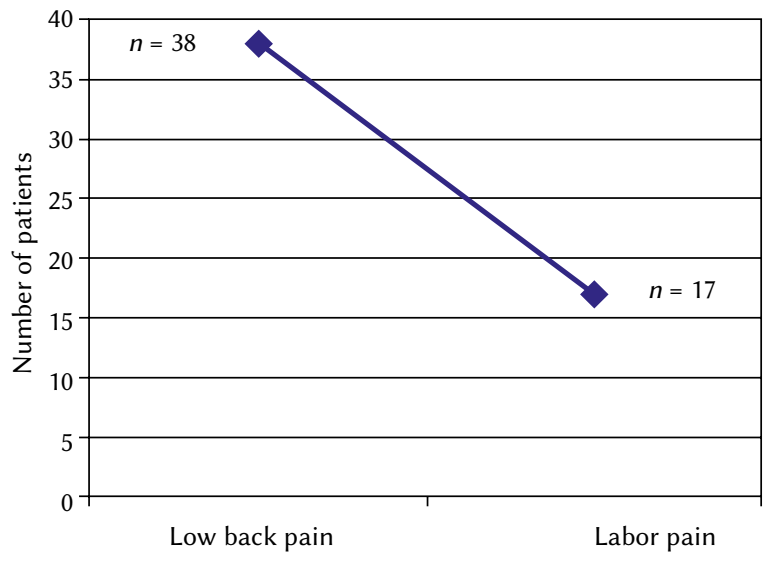

Figure 4. Prevalence of maximal labor pain and maximal low back pain in all the women participating in this study.

$11.0 \pm 5.1$ years prior to the consultation. The average age at neurosurgical consultation was $60.7 \pm 11.7$ years for Group A and $38.5 \pm 7.5$ years for Group B. Women of Group A scored their low back pain at an average level of $8.3 \pm 1.6 \mathrm{NRS}-11$ points, while the respective average score for Group B participants was $7.4 \pm 1.8$ points. The average scores for labor pain in Group A and $B$ were $8.3 \pm 2.1$ and $9.1 \pm 1.5$ NRS- 11 points, respectively. Student's $t$-test showed significant differences in the intensity of low back pain experienced by these two groups; low back pain reported by women from Group A was significantly stronger than that in Group B participants $(p=0.0085)$. Moreover, there was a significant intergroup difference in the intensity of

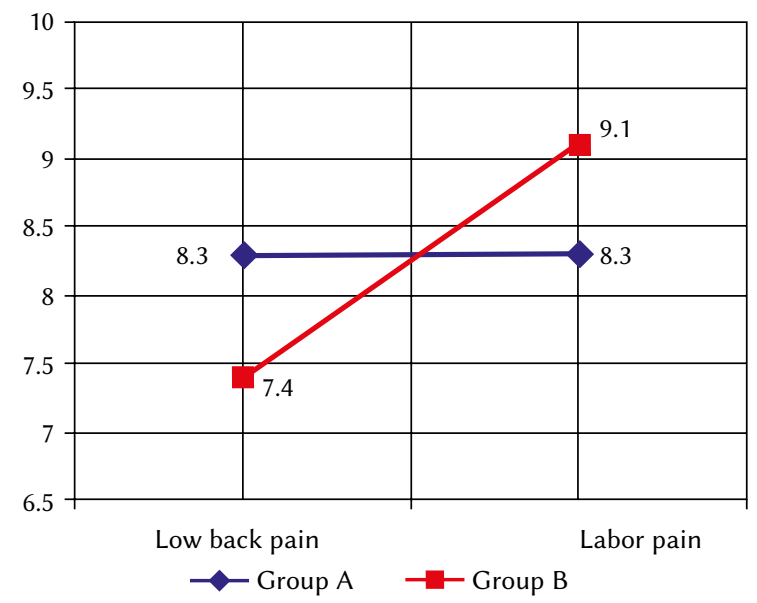

Figure 5. Mean intensity of low back pain and labor pain in "older" (Group A) and "younger" (Group B) women.

labor pain $(p=0.0242)$; women of Group A reported lower intensity of this type of pain when compared to Group B participants. The intensities of low back pain and labor pain experienced by these two groups are presented graphically in Figure 5.

No significant correlation was observed between the age at delivery and the intensity of labor pain (Pearson's coefficient of correlation, $r=-0.12$ ). Similarly, there was no significant correlation between the age at consultation and currently experienced intensity of low back pain $(r=0.09)$ or the intensity of previously experienced labor pain $(r=-0.09)$. Moreover, no association was observed between the intensity of low back pain and the number of deliv- 
eries $(r=-0.08)$ or the time period between delivery and present consultation $(r=0.14)$.

In four cases (7\%), the intensity of low back pain was re-scored upon asking about the intensity of previous labor pain: from 10 to $8(n=1), 10$ to $5(n=2)$, and from 9 to $5.5(n=1)$ NRS-11 points. All four women scored the intensity of their labor pain as 10 NRS-11 points.

Leszek

Herbowski, Magdalena Podolska

The Numeric Rating Scale (NRS-11) used in this study is a straightforward and patient-friendly instrument for the clinical evaluation of quantitative pain intensity; moreover, it is more practical than the Visual Analogue Scale (VAS) (Breivik et al., 2008). Our analysis suggests that the level of pain experienced during labor is higher than that associated with lumbosacral discopathy. Although women are no longer punished for demanding pain relief during labor, as in the case of Eufane MacAyane of Edinburgh, who was buried alive in 1591, we are still unable to control labor pain effectively (Tasnim, 2010). In our study, labor pain was considered unbearable (10 points according to the NRS-11 scale) in 67 cases, which corresponds to $59.8 \%$ of all analyzed deliveries. Only one woman ( $0.9 \%$ of all deliveries) perceived her labor pain as mild (3 points according to the NRS-11 scale). In the remaining cases, labor pain was perceived as moderate or strong (39.3\% of all deliveries). In total, unbearable labor pain (10 points according to the NRS-11 scale) was observed in as many as 38 women, which corresponds to $66.7 \%$ of all studied women. Seventeen women (15.2\% of all participants) declared their low back pain as unbearable, while in the remaining cases the pain was perceived as moderate or strong (84.8\%).

The average intensity of labor pain in women who delivered at full-term vaginally was $8.6 \pm 1.9$ points according to NRS-11, while the average score of low back pain was $7.9 \pm 1.7$ points. The average difference in the intensity of those two types of pain was 0.8 points and proved statistically significant $(p=0.0037)$. One patient with a history of three previous deliveries scored both low back pain and labor pain as unbearable (10 points in NRS-11) and described low back pain by saying that "the bones would open as in labor". According to another patient, also with a history of three labors, "labor pain is the same as low back pain”. This patient, however, scored labor pain and low back pain differently, assigning 10 and 8 NRS-11 points to each, respectively.

The re-scoring of the intensity of low back pain, observed in four women participating in this study upon being asked about the intensity of previously experienced labor pain, confirmed the role of the memory of previous pain in the perception of currently experienced pain (Lowe, 1996). Previous histo- ry of labor pain can be associated with lower declared intensity of subsequent low back pain, similar to previous experience of non-gynecologic pain, which is reflected by weaker perception of labor pain (Niven \& Gijsbers, 1984). Undoubtedly, the memory of pain constitutes a factor that modulates the perception of pain and makes it qualitatively different from the quantitative grading of its intensity.

\section{CONCLUSIONS}

Labor pain experienced during full-term vaginal delivery is characterized by significantly higher intensity as compared to low back pain.

The memory of pain experienced during previous labors can attenuate the intensity of discopathy-related low back pain.

\section{REFERENCES}

Banasiewicz, J. \& Wójtowicz, S. (2010). The quality of life after cesarean section. Acta Neuropsychologica, 8, 273-283.

Barkwell, D.P. (1991). Ascribed meaning: a critical factor in coping and pain attenuation in patients with cancer related pain. Journal of Palliative Care, 7, 5-14.

Bielawska-Batorowicz, E. (2006). Psychologiczne aspekty prokreacji [Psychological aspects of procreation] (pp. 183-221). Katowice: Biblioteka Pracownika Socjalnego.

Breivik, H., Borchgrevink, P.C., Allen, S.M., Rosseland, L.A., Romundstad, L., Hals, E.K., Kvarstein, G. \& Stubhaug, A. (2008). Assessment of pain. British Journal of Anaesthesia, 101, 17-24.

Bushnell, M.C., Villemure, C. \& Duncan, G.H. (2004). Psychophysical and neurophysiological studies of pain modulation by attention. In: D.D. Price \& M.C. Bushnell (eds.). Psychological methods of pain control: progress in pain research and management (Vol. 29, pp. 99-167). Seattle: IASP Press.

de Walden-Gałuszko, K. (2001). Psychologiczne aspekty bólu. Przewodnik Lekarza, 4, 58-59.

de Walden-Gałuszko, K. (2007). Psychologiczne aspekty bólu i jego leczenia. Medycyna Paliatywna w Praktyce, 1, 66-70.

de Walden-Gałuszko, K., Majkowicz, M., Janiszewska, J. \& Jankowska, B. (2008). Uwarunkowania psychologiczne percepcji bólu przewlekłego. Badanie porównawcze chorych z różnym patomechanizmem bólu. Psychoonkologia, 12, 1-6.

Fernandez, E. (2002). Anxiety, depression and anger in pain. (pp. 183-234). Dallas: Advanced Psychological Resources Inc.

Gallagher, R.M. \& Verma, S. (2004). Mood and anxiety disorders in chronic pain. In: R.H. Dworkin \& 
W.S. Breitbart (eds.). Psychosocial aspects of pain: progress in pain research and management (Vol. 27, pp. 139-178). Seattle: IASP Press.

Golec, A. \& Dobrogowski, J. (2004). Zaburzenia depresyjne i ból przewlekły. Ból, 5, 35-43.

Golec, A. (2000). Podstawy psychologii bólu. Nowa Klinika, 7, 933-938.

Golec, A. (2004). Psychologiczne aspekty bólu. In: J. Dobrogowski \& J. Wordliczek (eds.). Medycyna bólu [Pain Medicine] (pp. 72-87). Warszawa: Wydawnictwo Lekarskie PZWL.

Hadjistavropoulos, H.D. \& Craig, K.D. (1994). Acute and chronic low back pain: cognitive, affective, and behavioral dimensions. Journal of Consulting \& Clinical Psychology, 62, 341-349.

Hawker, G.A., Mian, S., Kendzierska, T. \& French, M. (2011). Measures of adult pain. Arthritis Care and Research, 63 (Suppl. 11), S240-S252.

IASP (2012). Website of the International Association for the Study of Pain: http://www.iasp-pain.org/. (Accessed: March 3 ${ }^{\text {rd }}, 2012$ ).

Kerns, R.D., Rosenberg, R. \& Jacob, M.C. (1994). Anger expression and chronic pain. Journal of Behavioral Medicine, 17, 57-67.

Lowe, N.K. (1996). The pain and discomfort of labor and birth. Journal of Obstetric, Gynecologic \& Neonatal Nursing, 25, 82-92.

Niven, C. \& Gijsbers, K. (1984). A study of labour pain using the McGill Pain Questionnaire. Social Science \& Medicine, 19, 1347-1351.

Parada-Turska, J., Piotrowski, M. \& Szczepański, L. (2002). Medyczne i pozamedyczne problemy bólu przewlekłego. Reumatologia, 40, 250-256.

Podolska, M. \& Majewska, A. (2007). Lęk jako stan i jako cecha w grupie kobiet, u których zakończono ciążę za pomocą cięcia cesarskiego. Kliniczna Perinatologia i Ginekologia, 43, 56-60.

Podolska, M. (2001). Sposoby walki z lękiem i stresem u kobiet rodzących w opiniach personelu medycznego szpitalnych oddziałów położniczych. Zeszyty Naukowe Uniwersytetu Szczecińskiego, 311, 113-123.

Tasnim, S. (2010). Perception about pain relief during normal labour among health care providers conducting delivery. Medicine Today, 22, 20-23. 